\title{
Studies on a New Antiallergic Pyridinecarboxamide TA-5707F and Its Sodium Salt (TA-5707) II. Mechanism of Antiallergic Action of TA-5707
}

\author{
Kei TSUZURAHARA, Setsuko ISHIKAWA, Yasutoshi ONO, \\ Takashi MURATA, Matsuo KIKUCHI and Shigeyuki TAKEYAMA \\ Biological Research Laboratory, Tanabe Seiyaku Co., Ltd., \\ 2-2-50, Kawagishi, Toda, Saitama 335, Japan
}

Accepted May 25, 1987

\begin{abstract}
Mechanism of the antiallergic action of 6 -methyl- $N$ - $(1 H$-tetrazol-5-yl)2 -pyridinecarboxamide (TA-5707F) was studied using the water-soluble sodium salt (TA-5707). 1) TA-5707 administered p.o. at the dose ca. 3 times the ID50 for the PCA reaction did not inhibit capillary dye leakage induced on the rat skin by intracutaneous injection of histamine, serotonin, bradykinin and leukotriene $D_{4}$ $\left(\mathrm{LTD}_{4}\right)$. 2) TA-5707, at concentrations above $10^{-7} \mathrm{M}$. inhibited antigen-induced histamine release and dye leakage in the rat peritoneal cavity (passive peritoneal anaphylaxis). 3) TA-5707 inhibited both anaphylactic and compound 48/80induced histamine release from the rat peritoneal mast cells, the 1050 being $\mathrm{ca}$. $10^{-5} \mathrm{M}$ in both cases. It was concluded that TA-5707F exerts its antiallergic action by inhibiting the release of chemical mediators from sensitized cells.
\end{abstract}

In the previous paper, we reported on the PCA-inhibitory activities of a new orally effective antiallergic agent [6-methyl- $N$ $(1 \mathrm{H}$-tetrazol-5-yl)-2-pyridinecarboxamide (TA-5707F)] and its sodium salt (TA-5707) (1). When administered orally to rats. TA$5707 \mathrm{~F}$ and TA-5707 were bioequivalent, affording nearly identical time courses of response with a peak at 5 min after administration, and their ID50 values were both about $1 \mathrm{mg} / \mathrm{kg}$. The finding that TA-5707 exhibited little or no activity in inhibiting the PCA reaction when administered after challenge and the presence of crosstachyphylaxis between TA-5707 and disodium cromoglycate (DSCG) suggested that its mechanism of action is likely to be inhibition of anaphylactic release of mediators from the mast cell.

In the present paper, we report results of further studies on the mechanism of action. using in vivo and in vitro systems of rats and guinea pigs. Since the active entity is the same for TA-5707F or TA-5707, all experiments reported here were performed with water-soluble TA-5707.

\section{Materials and Methods}

Animals: Male Sprague-Dawley rats (ca. $200 \mathrm{~g}$ in body weight) and Hartley guinea pigs (ca. $250 \mathrm{~g}$ ) were purchased from Shizuoka Laboratory Animal Center and maintained on laboratory chow before use. The rats were used without fasting, because reproducible antiallergic effects of orally administered TA-5707 or TA-5707F were observed with non-fasted animals as described in the previous study (1).

Vascular permeability in the rat skin: Five $\mathrm{mg}$ of Evans blue in $0.5 \mathrm{ml}$ saline was injected intravenously to groups of rats, and a $0.05 \mathrm{ml}$ aliquot of saline or a saline solution of histamine ( $50 \mathrm{nmole}$ ), serotonin ( $5 \mathrm{nmole}$ ). bradykinin (50 nmole) or LTD $_{4}$ (3 nmole) was injected intracutaneously on the back of a rat. The amounts of the mediators used were determined after a preliminary test and are comparable with those reported elsewhere $(2,3)$. After $30 \mathrm{~min}$, the dimensions of the blueing areas (the largest diameter times its 
perpendicular diameter expressed in $\mathrm{cm}^{2}$ ) were measured.

Passive peritoneal anaphylaxis (PPA): The method described by Ross et al. (4) was modified as follows. Rats were first injected intraperitoneally with $2 \mathrm{ml}$ of 3 -fold diluted rat antiserum rich in $\mathrm{lgE}$ antibodies to Ascaris suum protein. Two hr later, the passively sensitized peritoneal mast cells were challenged in situ by injecting intraperitoneally $9 \mathrm{ml}$ of Tyrode's solution containing $4 \mathrm{mg}$ of Ascaris suum protein. 10 \%g of indomethacin and $100 \mathrm{U}$ of heparin. Test drugs dissolved in $1 \mathrm{ml}$ of Tyrode's solution were injected intraperitoneally $30 \mathrm{sec}$ before the antigen injection. After $10 \mathrm{~min}$, the rats were decapitated, and the peritoneal fluid was collected and centrifuged. Histamine was measured by the method of Shore et al. (5), and SRS-A was determined by the biological method using a guinea pig ileum suspended in a Magnus bath containing atropine and pyrilamine (both $10^{-6} \mathrm{M}$ ). Concentrations of the test drug were expressed as final concentrations in the solution injected into the peritoneal cavity (total of $10 \mathrm{ml}$ ).

Anaphylactic leakage of dye was induced in another group of sensitized rats by injecting them intravenously with $0.5 \mathrm{ml}$ of saline containing $5 \mathrm{mg}$ of Evans blue immediately before treatment with the drug and challenging as described above, except that indomethacin was omitted. The rats were decapitated $30 \mathrm{~min}$ after the challenge. Amounts of the dye leaked were measures spectrophotometrically at the wavelength of $625 \mathrm{~nm}$ with a Hitachi Perkin-Elmer 139 US-VIS spectrophotometer and calculated from a standard curve obtained with known amounts of the dye dissolved in Tyrode's solution. Effects of the test compound were expressed as percent inhibition compared with the control.

Histamine-induced dye leakage into the peritoneal cavity: Rats were intravenously injected with $5 \mathrm{mg}$ of Evans blue in $0.5 \mathrm{ml}$ saline and intraperitoneally injected with 1 $\mathrm{ml}$ Tyrode's solution containing TA-5707. After $30 \mathrm{sec}$, histamine plus $100 \mathrm{U}$ of heparin in $9 \mathrm{ml}$ Tyrode's solution were injected in traperitoneally to the above rats. After $30 \mathrm{~min}$, the peritoneal fluid was collected and cen- trifuged, and the amount of the dye in the supernatant was measured as described above. Concentrations of histamine and TA5707 are expressed as final concentrations in the solution injected into the peritoneal cavity (total of $10 \mathrm{ml}$ ).

Anaphylactic release of histamine from sensitized rat mast cells: Rats were passively sensitized by intraperitoneal injection of rat anti-Ascaris suum antiserum as described above. Two hr later, the rats were bled by decapitation and injected intraperitoneally with 5 $\mathrm{ml}$ of "mast cell medium" ( $\mathrm{MCM}$ containing $150 \mathrm{mM} \mathrm{NaCl}, 3.7 \mathrm{mM} \mathrm{KCl}, 3.0 \mathrm{mM} \mathrm{Na}_{2} \mathrm{HPO}_{4}$. $3.5 \mathrm{mM} \mathrm{KH}_{2} \mathrm{PO}_{4}, 0.9 \mathrm{mM} \mathrm{CaCl}_{2}, 5.6 \mathrm{mM}$ dextrose, $0.1 \%(\mathrm{~W} / \mathrm{V})$ bovine serum albumin, $0.1 \%(\mathrm{w} / \mathrm{v})$ gelatin, and heparin, $10 \mathrm{U} / \mathrm{ml}$, $\mathrm{pH} 6.80$ ) (6). After mild massage over the abdomen for ca. $2 \mathrm{~min}$, the peritoneal fluid was collected, from which peritoneal exudate cells (PECs) containing sensitized mast cells were harvested by centrifugation $(100 \times \mathrm{G}$, $5 \mathrm{~min}$ ) at $4^{\circ} \mathrm{C}$, and then washed with and resuspended in $\mathrm{MCM}$. The number of mast cells stained by toluidine blue was counted under a microscope. PECs containing $4.8 \times 10^{4}$ mast cells per tube were incubated at $37^{\circ} \mathrm{C}$ for $15 \mathrm{~min}$ with $200 \mathrm{\mu g}$ Ascaris suum protein in the presence of $20 \mu \mathrm{g}$ of phosphatidylserine in a final volume of $2 \mathrm{ml}$. The reaction mixture was then chilled and centrifuged $(1100 \times \mathrm{G}, 10 \mathrm{~min})$ at $4^{\circ} \mathrm{C}$, and the supernatant was boiled for $5 \mathrm{~min}$. Histamine content of the deproteinized supernatant was determined. The cells were resuspended in MCM and boiled for $5 \mathrm{~min}$, and histamine in the supernatant was also determined to calculate the total amount of histamine in the incubation tube (7). TA-5707 and DSCG were dissolved in $0.2 \mathrm{ml}$ MCM. prewarmed at $37^{\circ} \mathrm{C}$, and added to the incubation mixture 1.5 or $0.5 \mathrm{~min}$, respectively, before addition of the antigen. The release-inhibiting activities of the test compounds were expressed as percent inhibition.

Compound 48/80-induced release of histamine from rat mast cells: Rat peritoneal exudate cells containing $3.8 \times 10^{4}$ mast cells per tube were suspended in MCM solution. TA -5707 or DSCG was added 1.5 or $0.5 \mathrm{~min}$, respectively, before the addition of compound $48 / 80(0.5 \mathrm{~kg} / \mathrm{m} !)$. Incubation was 
continued for $15 \mathrm{~min}$. The incubation mixtures were prepared in duplicate or triplicate.

Anaphylactic release of histamine from minced guinea pig lung tissue sensitized in vitro with rabbit antiserum: As described before (8), minced guinea pig lung tissue was passively sensitized in vitro with rabbit antiserum to ovalbumin. The sensitized tissue was preincubated with various concentrations of TA-5707 at $37^{\circ} \mathrm{C}$ for $15 \mathrm{~min}$, and challenged by incubation with ovalbumin for further $15 \mathrm{~min}$. Histamine released into the medium was measured.

Chemical and biological materials: Ascaris suum antigen and rat antiserum to the antigen were prepared according to the methods reported previously (8). The antibody titer of the antiserum was 80 as evaluated by the homologous $\mathrm{PCA}$ reaction. TA-5707, $\mathrm{LTD}_{4}$ and FPL-55712 were synthesized in the Organic Chemistry Research Laboratory of this company. Inta|(F) (Fujisawa Pharmaceutical Co., Ltd., a 1:1 mixture of DSCG and lactose). Evans blue, histamine dihydrochloride and serotonin complexed with creatinine sulfate (Tokyo Chemical Industry $\mathrm{Co}$. Ltd), bradykinin (Protein Research Foundation), ovalbumin, compound 48/80, indomethacin and pyrilamine maleate (Sigma Chemical Company), and methysergide hydrogen maleate (Sandoz
Ltd.) were all commercial products.

Statistical evaluation: Results are expressed as means $\pm S . F$, and the statistical significance was calculated using Student's unpaired $t$-test

\section{Results}

Effect of TA-5707 on vascular permeability in the rat skin: Since the peak of PCA inhibition by orally administered TA-5707 appeared as early as 5 min after administration (1), the effect of the drug on the vascular dye leakage induced by allergic mediators was tested by injecting the mediators intracutaneously $5 \mathrm{~min}$ after oral administration of TA-5707 (Table 1). In the range of doses effective for suppressing the $\mathrm{PCA}$ reaction (1), oral administration of TA-5707 did not inhibit dye leakage in the rat skin induced by intracutaneous injection of histamine, serotonin, bradykinin or $\mathrm{LTD}_{4}$. Table 2 shows that these dye leakage reactions were specifically inhibited by the respective antagonists. In these experiments, TA-5707 rather somewhat stimulated the bradykinininduced dye leakage, but this effect was not dose-dependent and probably irrelevant. A tendency of slight stimulation of the histamine-induced dye leakage by TA-5707 was also observed.

Effect of TA-5707 on PPA in rats: TA-

Table 1. Effect of TA-5707 on histamine-, serotonin-, bradykinin- and leukotriene $\mathrm{D}_{4}$-induced dye leakage in the rat skin

\begin{tabular}{|c|c|c|c|c|c|c|c|}
\hline \multirow{2}{*}{$\begin{array}{l}\text { Experi- } \\
\text { ment }\end{array}$} & \multirow{2}{*}{ Compound } & \multirow{2}{*}{$\begin{array}{l}\text { Route of } \\
\text { adminis- } \\
\text { tration }\end{array}$} & \multirow{2}{*}{$\begin{array}{c}\text { Dose } \\
(\mathrm{mg} / \mathrm{kg})\end{array}$} & \multirow{2}{*}{$N$} & \multicolumn{3}{|c|}{ Dye leakage (blueing area in $\mathrm{cm}^{2}$ ) induced with } \\
\hline & & & & & $\underset{(-)}{\text { Saline }}$ & $\begin{array}{l}\text { Histamine } \\
\text { (50 nmole) }\end{array}$ & $\begin{array}{l}\text { Serotonin } \\
\text { (5 nmole) }\end{array}$ \\
\hline \multirow[t]{4}{*}{1} & \multirow{4}{*}{$\begin{array}{l}\text { Saline } \\
\text { TA-5707 }\end{array}$} & 0.0 . & - & 6 & $0.30 \pm 0.03^{a}$ & $1.18 \pm 0.12$ & $1.72 \pm 0.15$ \\
\hline & & p.o. & 0.3 & 6 & $0.36 \pm 0.03(1)^{\mathrm{l}}$ & $1.15 \pm 0.14$ & $1.84 \pm 0.14$ \\
\hline & & & 1 & 6 & $0.34 \pm 0.07(1)$ & $1.15 \pm 0.16$ & $1.78 \pm 0.14$ \\
\hline & & & 3 & 6 & $0.38 \pm 0.02(1)$ & $1.41 \pm 0.06$ & $1.76 \pm 0.06$ \\
\hline & & & & & $\begin{array}{c}\text { Saline } \\
(-)\end{array}$ & $\begin{array}{l}\text { Bradykinin } \\
\text { (50 nmole) }\end{array}$ & $\begin{array}{l}\text { Leukotriene } \mathrm{O}_{4} \\
\text { (3 nmole) }\end{array}$ \\
\hline \multirow[t]{4}{*}{2} & Saline & p.o. & - & 6 & $0.29(5)$ & $2.12 \pm 0.11$ & $1.21 \pm 0.07$ \\
\hline & TA- 5707 & p.o. & 0.3 & 6 & $0.26 \pm 0.05$ & $2.56 \pm 0.12^{*}$ & $1.23 \pm 0.07$ \\
\hline & & & 1 & 6 & $0.31 \pm 0.05$ & $2.46=0.09^{*}$ & $1.46 \pm 0.02$ \\
\hline & & & 3 & 6 & $0.35 \pm 0.04$ & $2.23 \pm 0.10$ & $1.26 \pm 0.09$ \\
\hline
\end{tabular}

Rats were treated with TA-5707, p.o. immediately after i.v. injection of Evans blue. Five min after the TA-5707 treatment, saline and mediator solutions were injected i.c. on the back skin. ${ }^{*} P<0.05$, by $S$ tudent's $t$-test. " standard errors of the mean. "Number of rats showing a response too faint to make correct measurements of diameteres of the blueing area are shown in parentheses. 
Table 2. Effects of pyrilamine, methysergide, FPL-55712 and TA-5707 on histamine-, serotonin- and leukotriene $\mathrm{D}_{4}$-induced dye leakage (blueing area in $\mathrm{cm}^{2}$ ) in the rat skin

\begin{tabular}{|c|c|c|c|c|c|c|c|c|}
\hline \multirow{2}{*}{$\begin{array}{l}\text { Experi- } \\
\text { ment }\end{array}$} & \multirow[t]{2}{*}{ Compound } & \multirow{2}{*}{$\begin{array}{l}\text { Route of } \\
\text { adminis- } \\
\text { tration }\end{array}$} & \multirow{2}{*}{$\begin{array}{c}\text { Dose } \\
(\mathrm{mg} / \mathrm{kg})\end{array}$} & \multirow[t]{2}{*}{$N$} & \multicolumn{4}{|c|}{ Dye leakage (blueing area in $\mathrm{cm}^{2}$ ) induced with } \\
\hline & & & & & $\underset{(-)}{\text { Saline }}$ & $\begin{array}{l}\text { Histamine } \\
\text { (50 nmole) }\end{array}$ & $\begin{array}{l}\text { Serotonin } \\
(5 \text { nmole })\end{array}$ & $\begin{array}{l}\text { Leukotriene } \mathrm{D}_{4} \\
(3 \text { nmole })\end{array}$ \\
\hline \multirow[t]{6}{*}{1} & Saline & p.o. & - & 6 & $0.05 \pm 0.03$ & $1.13 \pm 0.07$ & $1.53 \pm 0.16$ & \\
\hline & Pyrilamine & i.v. & 1 & 5 & $0.03 \pm 0.03$ & $0.75 \pm 0.04^{* *}$ & $1.62 \pm 0.15$ & \\
\hline & & & 3 & 5 & $0.03 \pm 0.03$ & $0.40 \pm 0.09^{* * *}$ & $1.32 \pm 0.08$ & \\
\hline & Methysergide & i.v. & 1 & 5 & $0.20 \pm 0.00$ & $1.25 \pm 0.03$ & $0.27 \pm 0.04^{* * *}(1)$ & \\
\hline & & & 3 & 5 & $0.20 \pm 0.10(2)$ & $1.33 \pm 0.14$ & $0.31 \pm 0.18^{* *}(2)$ & \\
\hline & TA-5707 & p.o. & 3 & 5 & $0.36 \pm 0.04$ & $1.38 \pm 0.04^{*}$ & $1.73 \pm 0.14$ & \\
\hline \multirow[t]{3}{*}{2} & Saline & p.o. & - & 4 & & $0.82 \pm 0.06$ & $1.32 \pm 0.09$ & $1.05 \pm 0.09$ \\
\hline & FPL-55712 & i.v. & 3 & 4 & & $0.97 \pm 0.06$ & $1.42 \pm 0.15$ & $0.53 \pm 0.09^{* *}(1)$ \\
\hline & TA-5707 & p.o. & 3 & 4 & & $1.04 \pm 0.10$ & $1.50 \pm 0.16$ & $1.23 \pm 0.02$ \\
\hline
\end{tabular}

See the legend for Table 1. Pyrilamine, methysergide or FPL-55712 was given i.v, together with Evans blue immediately before the i.c. injection of saline and mediator solutions. ${ }^{* *} \mathrm{P}<0.01,{ }^{* *} \mathrm{P}<0,001$ by Student's $t$-test. 
5707 and DSCG showed concentrationdependent inhibitions of antigen-induced histamine release (Fig. 1A) and dye leakage (Fig. 1B) into the peritoneal cavity. TA-5707 was more active than DSCG in both indices of PPA, but the shapes of the concentrationinhibition curves for TA-5707 (and DSCG) were not the same in the two anaphylactic reactions: i.e., the inhibition of histamine release by TA-5707 leveled off at $10^{-5} \mathrm{M}$. while that of dye leakage reached $100 \%$ at the same concentration.

The inhibition of antigen-induced dye leakage shown in Fig. $1 \mathrm{~B}$ could arise from antagonism of the test drugs to anaphylactic mediators. Out of the possible mediators, histamine has been reported to contribute to $60 \%$ of the amount of dye leaked in rat PPA (4). Therefore, we investigated the effect of TA-5707 on histamine-induced dye leakage. From the curve of dye leakage against the intraperitoneal dose of histamine (data not shown), the dose of $300 \mu \mathrm{g} / \mathrm{rat}(30 \mu \mathrm{g} / \mathrm{ml}$ peritoneal fluid). which caused an appropriate degree of dye leakage (i.e., $15.0 \mu \mathrm{g} / \mathrm{ml}$

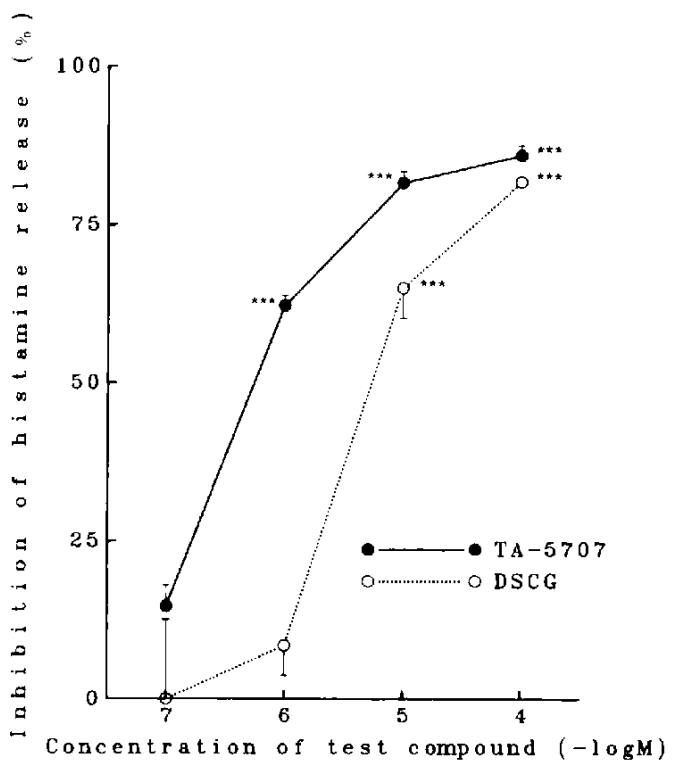

(A) compared with $19.5 \mu \mathrm{g} / \mathrm{ml}$ in PPA reaction), was chosen for this purpose. Addition of $10^{-5} \mathrm{M} \mathrm{TA}-5707$ to the peritoneal cavity, which fully inhibited dye leakage in PPA, did not affect the histamine-induced dye leakage (Table 3).

The amount of SRS-A released into the peritoneal cavity by antigen challenge in control rats was not high enough to be detected by the method with guinea pig ileum.

Effect of TA-5707 on histamine release from rat peritoneal mast cells: Effects of TA5707 and DSCG on anaphylactic histamine release from sensitized rat peritoneal mast cells were tested (Fig. 2). TA-5707 inhibited the release at concentrations above $10^{-6} \mathrm{M}$. The inhibitory activity of TA-5707 was higher at $10^{-6}$ and $10^{-5} \mathrm{M}$, but lower at $10^{-8}$. $10^{-7}$ and $10^{-4} \mathrm{M}$, than that of DSCG.

Lactose, which was present as an inert substance in the DSCG preparation $|n t a|^{\sqrt{B}}$, did not inhibit histamine release at concentrations expected to accompany DSCG (data not shown). TA-5707 did not affect the spontaneous release in the range of concen-

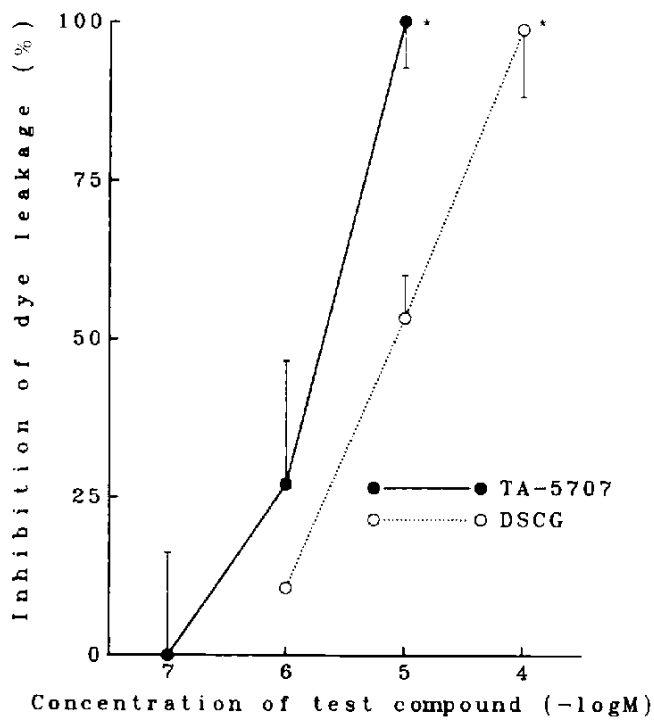

(B)

Fig. 1. Effects of TA-5707 and DSCG on the rat PPA reaction. The passively sensitized mast cells were challenged with the antigen in situ in the peritoneal cavity in the presence of TA-5707 or DSCG. See the text for other conditions. ${ }^{*} P<0.05,{ }^{* * *} P<0.001$, by Student's $t$-test. (A) Release of histamine from the peritoneal mast cells. $N=4$, except for the group treated with $10^{-7} \mathrm{MTA}-5707(\mathrm{~N}=3)$. (B) Dye leakage into the peritoneal cavity. $N=4-5$. 
Table 3. Effect of TA-5707 on histamine-induced dye leakage into the peritoneal cavity

$\begin{gathered}\text { Concentration } \\ \text { of TA-5707 }\end{gathered}$
$\begin{gathered}\text { Tyrode } \\ 10^{-7} \mathrm{M}\end{gathered}$
$10^{-6} \mathrm{M}$

Evans blue (i.v.), various amounts of TA-5707 (i.p.), and then a Tyrode's solution containing heparin and $30 \mu \mathrm{g} / \mathrm{ml}$ of histamine (i.p.) were iniected into rats. Thirty min later, the amount of the dye in the peritoneal fluid was measured. a No significant difference from the control group.

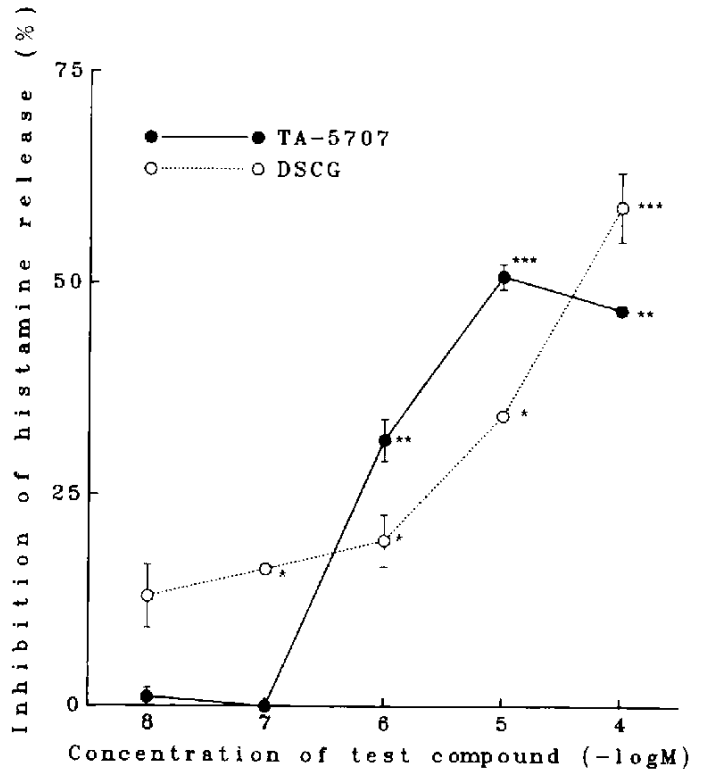

Fig. 2. Effects of antiallergics on anaphylactic release of histamine from sensitized rat mast cells in the presence of phosphatidylserine. All the incubation mixtures were prepared in triplicate. ${ }^{*} \mathrm{P}<0.05$ ${ }^{* * P}<0.01,{ }^{* *} P<0.001$, by Student's t-test.

trations of $10^{-8}-10^{-4} \mathrm{M}$ (data not shown)

TA-5707 also inhibited compound 48/80induced release of histamine from nonsensitized rat peritoneal mast cells. The concentration-inhibition curves for TA-5707 and DSCG (Fig. 3) were similar to those obtained in the system of anaphylactic histamine release (Fig. 2).

Net release of histamine by the antigen (Fig. 2) or by compound $48 / 80$ (Fig. 3) was $43.8 \pm 1.8 \%$ or $66.3 \pm 0.2 \%$, respectively, under the present conditions.

Effect of TA-5707 on anaphylactic release of histamine from sensitized lung tissue of

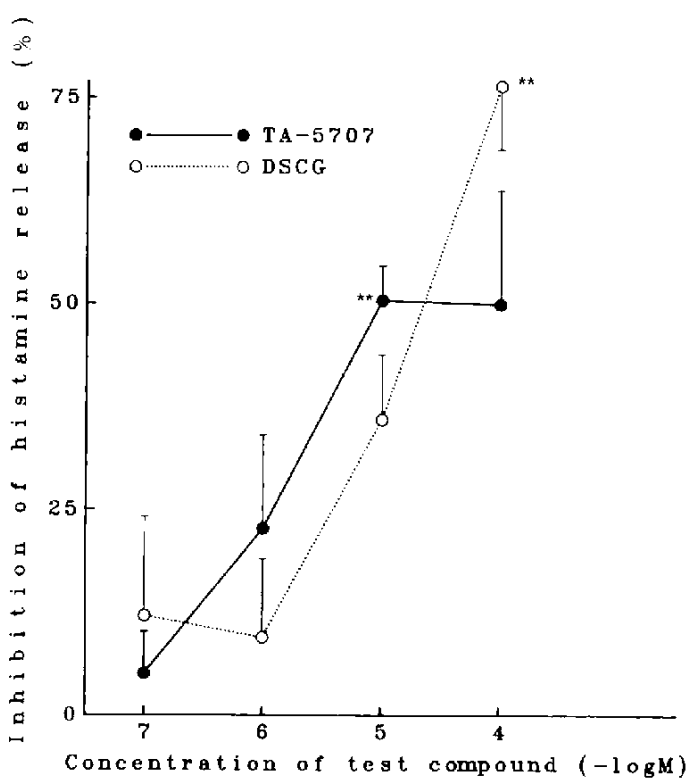

Fig. 3. Effects of antiallergics on compound 48/80. induced release of histamine from rat peritoneal mast cells. The incubation mixtures were prepared in duplicate or triplicate. ${ }^{*} P<0.01$, by Student's $t$-test.

guinea pigs: TA-5707 was also active in inhibiting anaphylactic release of histamine from guinea pig lung tissue (Table 4), but its inhibitory concentrations were higher than those required for the inhibition of histamine release from rat peritoneal mast cells.

\section{Discussion}

TA-5707 inhibited the PCA reaction in the rat when administered before the challenge, but it exerts little or no activity when given after the challenge (1). There was mutual cross-tachyphylaxis between the inhibitory actions of TA-5707 and DSCG, when large doses (ca. 30 times the ID50) were given (1). 
Table 4. Effect of TA-5707 on anaphylactic release of histamine from guinea pig lung tissue

$\begin{gathered}\text { Concentration } \\ \text { of TA-5707 }\end{gathered}$
$1.3 \times 10^{-3} \mathrm{M}$
$4.4 \times 10^{-3} \mathrm{M}$
$13.3 \times 10^{-3} \mathrm{M}$

The incubation mixtures were prepared in duplicate or triplicate. In the control tubes done in duplicate. the histamine release was $3.7 \mathrm{\mu g}$ histamine per $\mathrm{g}$ (wet weight) of the tissue.

Furthermore, TA-5707 inhibited antigeninduced bronchoconstriction (9), but did not affect serotonin-induced bronchoconstriction (K. Ikezawa et al., unpublished data) in rats. These observations may be taken as indirect evidence that TA-5707 exerts its action by inhibiting the release of allergic mediators rather than by antagonizing their actions.

Indeed, TA-5707 did not inhibit the skin reactions induced by exogenously injected allergic mediators at doses of TA-5707 ca. 3 times the ID50 for the PCA reaction (Table 1). These skin reactions were inhibited by the respective antagonists (Table 2 ).

The results discussed above were all indirect evidence that TA-5707 exerts its antiallergic effects by inhibiting the release of mediators from mast cells and not by antagonizing the mediator' actions. Direct evidence was obtained by the experiments which showed the inhibition of histamine release from rat peritoneal mast cells in two systems: one is the in vivo PPA (Fig. 1A) and the other is the in vitro release of histamine (Fig. 2). TA-5707 also inhibited dye leakage into the peritoneal cavity in PPA (Fig. 1B), but it did not inhibit histamine-induced dye leakage at the same concentrations (Table 3 ). TA-5707 was more potent than DSCG in inhibiting both histamine release and dye leakage in PPA (Fig. 1).

In the in vitro system of anaphylactic histamine release, the concentration-response (inhibition of release) curve for TA-5707 formed a plateau above $10^{-5} \mathrm{M}$ (Fig. 2), unlike the in vivo system, in which TA-5707 at $10^{-5} \mathrm{M}$ inhibited the release of histamine by more than $80 \%$ (Fig. 1A). This discrepancy might have been caused by the addition of phosphatidylserine in the in vitro system. because our unpublished data showed that with TA-5707, the inhibition percent was higher in the absence than in the presence of phosphatidylserine, which enhances the release of histamine. It has been reported that DSCG is a partial antagonist of the anaphylactic release of histamine from human lung tissue even in the absence of phosphatidy/serine (10).

TA-5707 also inhibited compound 48/80induced release of histamine from rat peritoneal mast cells (Fig. 3), the potency being the same as that obtained in the anaphylactic release. Thus, TA-5707 might affect, among the sequential events of histamine release, a step or steps common to the two different systems of histamine release.

In the anaphylactic release of histamine from sensitized lung fragments of guinea pig. the inhibitory activity of TA-5707 was lower than the inhibitory activity in the rat peritoneal system. This result suggests that the inhibitory activity of TA-5707 on mediator release might differ from species to species.

in humans, TA-5707 was effective in suppressing allergic skin responses in house dust-sensitive volunteers (11) and symptoms of allergic rhinitis in atopic patients (12). Thus, TA-5707 and TA-5707F [see (1)] are expected to be useful therapeutic agents against allergic diseases in clinical practice

Acknowledgment: The authors are grateful to Dr. $H$. Nakajima, Director of this laboratory, for his constant encouragement throughout these studies.

\section{References}

1 Tsuzurahara, K., Murata, T., Ishikawa, S., Date, T. and Takeyama, S.: Studies on a new antiallergic pyridine-carboxamide TA-5707F and its sodium salt (TA-5707). I. Inhibition of $\mathrm{lgE}$ induced passive cutaneous anaphylaxis (PCA) in rats. Japan. J. Pharmacol, 40, 37-46 (1986)

2 Kuriki, H., Saijo, T., Maki, Y. and Kanno, M.: Antiallergic action of 6-ethyl-3-(1/-tetrazol-5- 
yi) chromone (AA-344) on immediate hypersensitivity reaction in rats. Japan. J. Pharmacol. 29, 385-397 (1979)

3 Ueno, A., Tanaka, K., Katori, M., Hayashi, M. and Arai, $Y$.: Species difference in increased vascular permeability by synthetic leukotriene $C_{4}$ and $D_{4}$. Prostaglandins 21, 637-648 (1981)

4 Ross, J.W., Smith, H. and Spicer, B.A.: Increased vascular permeability during passive peritoneal anaphylaxis in the rat. The effects of disodium cromoglycate and a nitroindanedione. Int. Arch. Allergy Appl. Immunol. 51, 226-237 (1976)

5 Shore, P.A., Burkhalter, A. and Cohn, V.H., Jr.: A method for the fluorometric assay of histamine in tissues. J. Pharmacol. Exp. Ther. 127, 182-186 (1959)

6 Sullivan, T.J., Parker, K.L., Stenson, W. and Parker, C.W.: Modulation of cyclic AMP in purified rat mast celis. I. Responses to pharmacologic, metabolic, and physical stimuli. J. immunol. 114, 1473-1479 (1975)

7 Burdon, K.L. and Schultz, A.: Inhibiting effect of histamine from guinea pig lung by specific antigen. J. Allergy 38, 100-107 (1966)

8 Tsuzurahara, K., Ono, Y., Ogiwara, K., Murata, T. and Takeyama, S.: Antiallergic effects of the adrenergic $\beta$-stimulant trimetoquinol in rats and guinea pigs. Chem. Pharm. Bull. (Tokyo) 27. 1715-1724 (1979)

9 Tsuzurahara, K., Ikezawa, K., Ono, Y., Murata, T. and Ishikawa, S.: Antiallergic activity of a new pyridinecarboxamide derivative, TA-5707. Japan. J. Pharmacol. 33, Supp. 122P (1983)

10 Young, K.D. and Church, M.K.: Passive anaphylaxis in human lung fragments as a model for testing anti-allergic drugs: its variability and constraints. Int. Arch. Allergy Appl. immunol. 70, 138-142 (1983)

11 Saito, Y.: Clinical pharmacological evaluation of a new anti-allergic agent. TA-5707, by skin and nasal provocation tests, Japan. J. Clin. Pharmacol. Ther. 15, 507-516 (1984) (Abs. in English)

12 Ohashi, Y., Nakai, Y., Takeichi, N., Maruoka, K., Minowa, Y., Harada, H., Nakata, J., Kihara, S., Ikeoka, H., Koshimo, H., Kuroki, K. and Takano, $H$.: Protective effect of a pyridine-carboxamide derivative TA-5707 on the nasal provocation. Oto-Rhino-Laryngology Tokyo 27, Supp. $241-$ 249 (1984) (in Japanese) 